\title{
Theoretical Foundations of the Research of Dialectics of Semantic Relations
}

\section{Pokrovska Iryna L.}

\author{
Associate Professor Turkic Studies Institute of Philology, Kyiv National Taras Shevchenko University
}

Email: 2894848@gmail.com

Doi:10.5901/mjss.2015.v6n3s1p607

\begin{abstract}
The concept of dialectics from ancient times to the present is reviewed in this study. In particular, the views of scientists of ancient Greece and medieval Europe are analyzed in details; the attention is focused on the existing in modern dictionary definition of the term dialectic. The role and place of dialectics are analyzed in different fields of science including in linguistics. In modern linguistics, the dialectical semantics of word is a complex psychic component, in which the intellectual elements are dominant. In the basis of seme analysis is the concept of lexical meaning as a set of semantic components, which are smaller than the lexical meaning. The language is in the constant development, and therefore its nominative system is updated with new secondary names through which the dialectic of semantic relations is fixed in the language system.
\end{abstract}

Keywords: dialectic; semantic relations; linguistic forms; ambiguous words; secondary nomination; metaphor.

\section{Introduction}

Dialectics has been a feature of the philosophical theoretic reasoning since its origination. The notion of dialectics arose in the antic philosophy and was affected to some extent by the revolution in the medieval philosophy and the philosophy of Renaissance. «Materialistic dialectics» appeared in the works of F. Engels and remained in the countries of socialistic way of life. Nowadays dialectics is encountered in various spheres of science (including linguistics), yet one should deepen into history in order to conceive its particularities.

\section{Literature Review}

"The dialectic idea of harmony and struggle of opposites in its naive and apparent "figurative form was introduced by Homer in his "The Shield of Achilles", a brief summary of the "lliade" (Kissidi F.H., 1972). The rendering of the main life and being forms was arranged by Homer, an antic classic, according to the principle of opposites. "However, this opposition is not mere symmetry and the formal antithesis; it's an inner polarity, where the opposites are mutually causal constituting the unity" (Kissidi F.H., 1972).

The unmatched peculiarity of the antic dialectician was reflected in the following formula of A.F. Losev: antic dialectics - the "logos of eidos" - a way of establishing and removing controversies of reasoning (Losev, A.F., 1927).

Heraclitus notes that the world basis is changeable. His principle of "panta rei" (everything flows) explicates the idea of permanent movement and changes. For such ideas, he is still referred to as the first dialectician (Platonenko, O.M., 1999): "One thing transforms to another within its change process". <...> The fact of permanent change and transformation of things implies the controversial character of their existence. Consequently, existence is an eternal struggle of opposite elements. He (Heraclitus) called this struggle the law of world creation».

Some scholars call Heractius' antic dialectics along with antic dialectics in general "random", "spontaneous", "unthought" due to indivisibility of its general notions (llenkov, E.V., 1991).

Socrates, an antic philosophus, devises a specific concept of dialectics as the art of studying notions with the aim of conceiving the truth". This is performed in the dialog process. The purpose of a conversation, argue or dialog is to find the precise definition of a notion.

Pluto treats dialectics not only as logic, though it embraces a logic context as well, nor is dialectics a mere science of conceiving (yet it also includes a gnoseological aspect) and science of methodology (yet it also includes an aspect of methods). Dialectics in Pluto's understanding is primarily the science of existence and types of truthful existence (Asmus, V.F., 1976). Pluto's philosophy is called idealism and his dialectics is called idealistic. Pluto defines dialectics as the art of conducting an argument or dialog. Dialectician is considered a person, "who can raise questions and give answers". Socrates was somehow inclined to this statement, although he didn't consider his method of philosophy to be dialectics. 
The term "dialectics" (from Greek, "which concerns the conversation") was coined by Pluto.

Dialectics in Aristotle's understanding is not a science of the unity of contraries, but it is partly connected with logics. He contrasts dialectics to apodictics, which provides strict knowledge flowing from rigid beliefs into the process of its deductive proving. Aristotle's dialectics is attributed to "negative dialectics".

Medieval dialectics evolved within the bounds of scholastics. Dialectics was treated as a preparatory stage for the study of theology. "Dialectics was treated as a set of logical and rational techniques; scholiasts' practicing it made some of them think that there is a rational proof of the dogmas of Christianity" (Losev A.F., 1988).

S.S. Neretina expresses an interesting and uncommon point of view stating that in the Middle Age dialectic knowledge appears to be in priority. "Such kind of a meeting, with its scholastics and oral dialog that assumed the form of a dispute, made it possible to evolve dialectics and notions that were simultaneously directed to sacral and carnal - i.e. being ambivalent and shaping an absolutely different way of conceiving and philosophizing" (Neretina S.S.,1995).

Dialectics of the Middle Age is distinctive of the idea of the identity between the sacral and carnal in the dialectic philosophic reasoning.

Nicholas of Cusa (1401-1464), a German theologian, is a renowned representative of dialectics development. His dialectics stems from his understanding of God and the world, it also manifests itself in the doctrine of God, which gives birth to the world, where the finite will emanate from the eternal, the multiplicity from the oneness and a part from the whole. The very pathos of oneness and eternity is the definitive element of Nicholas' interpretation of God (Platonenko, O.M., 1999).

The main feature of the medieval dialectics was the desire of getting rid of the controversy between the celestial and terrestrial worlds and argumentation of its unity.

Consequently, dialectics as a way of philosophic reasoning had created a peculiar world perception system.

By Hegel's judgment dialectics is a peculiar logic of philosophic reasoning, which conceives the world on the basis of the unity of opposite notions. All things and phenomena are inseparably interrelated. The final stage of establishment of the dialectics within the Hegel's doctrine is the formation of the notion of dialectic logic (or so-called "idealistic logic") a systemized reasoning form and a way of world construction. Then the controversy becomes the higher reasoning stage for the human [109].

There is currently no single definition of dialectics, so we list them here in all their diversity. Nowadays there are

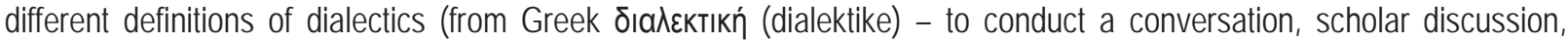
dialog), which should be grouped by the following principles and approaches.

\section{Findings and Discussion}

The term "dialectics" became popular owing to the Pluto's "Dialogues", where two or more dialogue participants could support different thoughts, although they aspired to find the truth by mean of exchange of their thoughts. In the "Ukrainian Language Dictionary" dialectics is primarily defined as being able to carry out a debate by using logical evidence. Apart from that, dialectics is a process of development and movement of something (This is dialectics, woman! You can't do nothing with it (Andriy Golovko, I, 1957, 489).

Regardless of that, dialectics is observed as a way of world perception, theory and method of conceiving, method of philosophy that studies the development categories.

The most spread approach to dialectics is its analysis as a notion, which reflects the development in course of interaction with controversies. Dialectics, in particular, is a kind of reasoning and understanding the world, thereby different phenomena and objects are observed in terms of their interrelation, interaction of opposing forces, trends of change and development process. Consequently, we perceive dialectics as a part of philosophy being applied to other fields of science, and we render by that different instances of development and controversy.

The term dialectics appeared in the ancient philosophy, however, at present stage it has become ingrained into various fields of science, in particular, there are known such compound terms as the "dialectics of nature", "dialectics of history", "dialectics of consciousness", "dialectics of cognition", "dialectics of a text".

It is required to distinguish a few word collocations from the theses of recent years connected with the evolvement of the notion "dialectics". In philosophy: dialectics of life and death (L. A. Tronina), religious text: dialectics of the content and interpretation (V. Y. Balabushevych), dialectics of the interrupted and uninterrupted (Y. A. Borodina), dialectics of the finite and endless (E. I. Danylova); in culturology: dialectics of interrelation between a city and village (Chyzhov); in economics: dialectics of the economic growth and inflation processes (V. N. Ryabyh), dialectics of competition and monopoly (N. N. Nikitina), dialectics of market and planned relations (G. I. Skoryk), dialectics of interplay of economic growth in post-industrial society (O. V.Kostyuchyk), pedagogy: dialectics of relation between socialization and individual 
personality of a school boy (A. N. Husiahmetov), biology: dialectics of interaction between the animate and inanimate nature (Y.V.Girusov); in art criticism: P.I. Tchaikovsky: dialectics of personality and style (Poberezhna G.I.).

Apart from fields of science mentioned below, dialectics is also an element of philological sciences.

The research of I.V. Stepanova, "Word and Music: Dialectics of Semantic Relations", stands at the boundaries of art criticism and philology. This work is dedicated to the interrelation between music and the word, though the very connection between the fields of science isn't something new, as the aspect of dialectics wasn't previously subject to a separate monographic research, despite the scientifically substantiated statements on the relation of the content frame of the verbal and musical texts. I. V. Stepanova analyzes issues of musical semantics, folklore refrains in the light of linguistics and the solutions of content secrets of various spheres of vocal art (Stepanova, I.V., 1999).

Among the works dedicated to dialectic relations in the study of literature one should primarily highlight the following ones: G.O. Zolotuhin had studied dialectics of the objective and subjective in the literary-critical creative activity, T.S. Vlaskina had studied dialectics of norms and values in the world of art, P.Y. Suvorova - dialectics of the common and individual in the versed style, O.A. Kovyrshyna - dialectics of time and eternity in the artistic mind.

The word as a language sign is the unity of the content plane and expression plane, and their relation is only intermediated in the human's mind (V. Gak, O. Luriya, N. Ufimtseva). Therefore, dialectic semantics of the word - is a complex psychical constituent, wherein intellectual elements are dominate. V. Gak distinguished the "separate meaning level" within one of the four levels of the lexical-semantic structure of the language, and "it is observed as a specific kind of the system structure, and it is, to some extent, an organized aggregate of semantic components". The semantic structure of a word in divided into macro- and microcomponents (elementary meaning units). The seme analysis is based upon the conception of the lexical meaning as an aggregate of semantic components, which are lesser than the lexical meaning. The main element of the semantic field is a word as any group of content units related to the same fragment of the realm that embraces any sphere of human experience. In terms of such treatment the semantic field is the reflection of the linguistic world image of a particular native speaker (V. Zvegyntsev). Generating a speech utterance, the human operates primarily semantic fields and selects among them lexical units, which are best meeting the communicative objectives (Gak A.A., 1971).

V.G. Gak in his article, "Dialectics of Semantic Relations in the Language", laid grounds for dialectics in the system, in particular, those semantic changes, which are characteristic of the language development. "Language forms easily change their referential correlation and sometimes lose any referential connection with every referent $\langle\ldots\rangle$ persistence and mobility of the word meanings are in the focus of linguists attention, moreover, one may say that if such semantic asymmetry didn't exist, other complicated features of the theoretical and practical study of languages would also fade away (Gak A.A., 1976).

The experiments of D. N. Uznadze in the sphere of psychology proved that a word is not randomly linked to an object, but it is based on the correspondence, where the word meaning and the speaker's conception of an object appear simultaneously (Uznadze D.N., 1966).

"The use of known language forms for nomination of new objects and situations corresponds to the fundamental feature of human psychology, which is the fact that the human is able to perceive new information only basing on some existing information. The human can not perceive anything, which is brand new. A previous notion, which is associated with some already known concepts, appears to be a bridge for the human consciousness to link the known with the unknown", V.G. Gak notes (Gak A.A., 1976).

At that, even philosophical researches prove that using an old term by its new meaning (a metaphor in the enlarged sense of a word) in science is a necessary phenomenon, as it somehow helps express the new through the already known.

Consequently only two possible ways of development of the language form are the transfer of meaning and desemantization: a word either receives a new figurative meaning (correlates with the denotatum) or is dramatized (loses its ability of its self-correlation with the denotatum); a word collocation is developed either by mean of phraseologization (transfer of meaning) or grammarization (analytical forms and constructions building).

The language is constantly developing, so its nomination system is being supplemented with new secondary nominations, which are not quite timely find its way into dictionaries. As a result, the majority of lexical units contain a primary and secondary nomination. V. M. Teliya notes that reconceived units do not change their material expression and become the basis for "the formation of words with multiple meaning and various kinds of phraseological units" (Teliya V.N., 1998). Secondary nomination is a feature of language signs denoting various spheres of human activities, for instance, one of the most prolonged links of associations, metaphors and metonymies is the peculiarity of religious notions, which have been assuming new meanings across the centuries within the society, and not only have they penetrated into the colloquial language, fiction and belles-lettres, but they also may be found in the columns of journalistic 
issues, speeches of politicians, etc.

The significant contribution to discovering the essence of the concept of secondary nomination was made by $\mathrm{C}$. Bally, V.G. Gak, O. Jespersen, O.S. Kubryakova, Ye. Kurylovych, A. Sechehaye, P.O. Soboleva, L. Tesnière, A. Frei. In recent years semantic transposition as a language phenomenon denoting processes of transfer of lexical meaning and building secondary nomination units - like metaphors, metonimies, etc. - became a subject for linguistic researches of recent years (Yu. V. Philippova, O. M. Shalifova).

Secondary nomination, according to N. P. Tropina, is the use of an old word (its external shell) for the purposes of new nomination. As a result, the word assumes a new meaning, and the word meaning multiplicity develops, which is already a semantic process being the study object of semasiology (Tropina N.V., 2003).

Linguists had started working on the problem of word semantics in the XIX century. In this context it is necessary to point out such surnames as St. Ullmann, B.Warren [UI.]. The main units representing the metaphoric meaning of a word is a metaphor and metonymy.

In case of metaphor some language form (a word, phrasal unit, etc.) is transferred from one referent to another (in the very language it is presented by its transition from one context of the content to another) not by itself but in the role of the indicator of the corresponding meaning (Taranenko A.A., 1989). Dogan Aksan, a Turkish linguist, by the analysis of metaphors he points out the transferring from the human to the nature (transfer of physical and moral features, which are characteristic of the human, and such poetic device is called personification (personification, kişileştirme) (bald steppes, dreamy evening, virgin lily) as well as transferring from nature to the human (swine, fox), transferring of senses (sweet words) (Aksan D., 2005).

G. Lakoff and M. Johnson define a language metaphor as a double collective categorization, which is based on the psychological reality of prototype models.

The following types of language metaphors can be subdivided according to the mechanism of origin: 1) the nominative metaphor (i.e. transferring a name), which accounts for the substitution of one descriptive meaning by another and serves as a source of the homonymy; 2) the image metaphor, which arises as a result of conversion of identifying (descriptive) meaning into predicative one and serves for the development of figurative meanings and synonymous means of a language; 3 ) the cognitive metaphor; 4) the generalizing metaphor.

As for metonymies, they are used for the purpose of transferring from one object to another without naming the very notion.

Metaphors and metonymies fix the dynamics of language development, they are in the state of permanent movement. It is appropriate to classify the language as somewhat of a "graveyard of metaphors": a word previously being a metaphor may lose its metaphoric features with the course of time. During the practical activity process people deal not with the surrounding world but with its representations, cognitive images and models.

\section{Concluding Remarks}

Consequently, a linguistic unit may be affected by two types of changes in terms of semantics: either to transform into another unit of the same class (the change in meaning) or cease to exist as a unit of some semantic class (desemantization). Thus, the linguistic unit can be affected in semantic relation, can turn into other unit of the same class (changing of meaning) or remain unchanged. At this dialectic of semantic relations is the ratio of the stability and variability of the semantic paradigm of linguistic units. Simultaneous stability and variability of semantic relations are necessary for the functioning and development of the language system. Simultaneous stability and variability of semantic relations are necessary for the functioning and development of the language system. Semantic stability of linguistic units is described in such terms as "invariant of word meaning", "primary and secondary meanings of the word". Semantic variability is reflected in the concept of lexical-semantic variants, contextual meanings, shades of meaning of words. Nowadays the research of such plan of semantic relations is extremely essential from the perspective of the interrelation of language and thought, which develop reflection semantics in linguistic, philosophical and psycholinguistic plans.

\section{References}

Aksan, D. (2005), Aktsent. Semantika i temyi v turetskom yazyike [Accent. The semantics and topics in Turkish], Engine Publishing House, Ankara, Turkey.

Asmus, V.F. (1976), Antichnaya filosofiya [Ancient Philosophy], Vyisshaya shkola, Moscow, Russia.

Gak, A.A. (1971), The semantic structure of the word as a component of the semantic structure of statements, Semanticheskaya struktura slova, Nauka. Moscow, Russia. 
Gak, V.G. (1976), By dialectic semantic relations in the language, Printsipyi i metodyi semanticheskih issledovaniy, Nauka. Moscow, Russia.

Ilenkov, E.V. (1991), Antique dialectic as a form of thought, Filosofiya i kultura, Political Literature Publishing House, Moscow, Russia. Kissidi, F.H. (1972), Ot mifa k logosu (Stanovlenie grecheskoy filosofii) [From myth to logos (Formation of Greek philosophy)], Thought, Moscow, Russia.

Losev, A.F. (1927), Antichnyiy kosmos i sovremennaya nauka [Ancient Cosmos and Modern Science], Izdanie avtora, Moscow, Russia.

Losev, A.F. (1988), The origin of the medieval nominalist dialectics. Erigena and Abelard, Istoriko-filosofskiy ezhegodnik, Nauka. Moscow, Russia.

Neretina, S.S. (1995), Abelard and features of medieval philosophizing, Abelyar P. Teologicheskie traktatyi, Progres, Gnozis. Moscow, Russia.

Slovnik ukrayinskoyi movi (1971), [Ukrainian Language Dictionary], Vol. 2, p. 294.

Platonenko, O.M. (1999), Dialectics as an attribute of philosophical theoretical thinking, Abstract of Ph.D. dissertation, Philosophy of science, Omsk State Pedagogical University, Omsk, Russia.

Stepanova, I.V. (1999) Word and RM: Dialectics of semantic relations, Abstract of of Ph.D. dissertation, Art History, The Moscow State Conservatory. P.I. Tchaikovsky, Moscow, Russia.

Taranenko, A.A. (1989), Yazyikovaya semantika v ee dinamicheskih aspektah (osnovnyie semanticheskie aspektyi) [The language semantics in its dynamic aspects (basic semantic aspects)], Naukova dumka, Kiev, Ukraine.

Teliya, V.N. (1998), Nomination, Bolshaya Sovetskaya Entsiklopediya. Yazyikoznanie, Ed. BRS, Moscow, Russia.

Tropina, N.V. (2003), Semantic derivation: multiparadigmality research", Ed. KSU, Kherson, Ukraine.

Uznadze, D.N. (1966), Psihologicheskie issledovaniya [Psychological research], Nauka. Moscow, Russia. 